English. In either case the name of the abstractor will be acknowledged in the : text and payment will be made at the rate of thirty shillings per thousand words. Since the literature from January 1, 1947 , is being dealt with, an early notification by potential abstractors would be much appreciated.

\title{
MR. SURPHLETE, AN ITEM OF OPHTHALMOLOGICAL HISTORY
}

BY

\author{
R. R. JAMES \\ WOODBRIDGE
}

IN Sloane MS. 3801 at the British Museum is mentioned the man whose name heads this paper. In my "Studies in Ophthalmological History" I gave a transcript of the manuscript in question, and may here repeat the lines dealing with Mr. Surphlete.

"Then ther was one Mr. Surphlete a man of axeolente Dyet and crusty fasion of bodye. He lived till he was fouere score yeares of age lived moste in Norfolke \& dyed at Linn and in good estate. He lay 2 or 3 yeares at a barber's house at Linn to whom he taught som skille, who nowe professethe it with weak Understandinge and gyven to drinke. I cannot com'end this Mr. Surphlete for any extraordinarye skille though of longe experience."

$\mathrm{Mr}$. Arnold Sorsby has called my attention to the fact that Richard Banister refers to the following oculists in the preface to his Breviary: "Henry Blackborne, famous for the forenamed cures; my kinde acquaintance Robert Hall, of Worcester; Master Velder, of FennieStanton; Master Surflet, of Lynne and Master Barnabie, of Peterborough, all excelling in these operations." He goes on to say that " in their case I noticed much practice but little theorie."

The name Surflet is very rare. Research has established the following facts. A small market town named Surflet is near Spalding in Lincolnshire. A Richard Surflytte married at Maplebeck, Notts., Isabel Lynne on 13, October 1563. A man of the same name (but spelt Surflet), matriculated sizar from Trinity College, Cambridge, at Michaelmas, 1576 (Venn). Richard Surflet, Practitioner in Physicke, translated Andreas Laurentius's " A Discourse of the Preservation of the Sight, and a Treatise of Melancholike Diseases, of Rheumes, and of Old Age." This book was printed by Felix Kingston, for Ralph Iacson, dwelling in Paules Churchyard at the Signe of the Swan, 1599. It is dedicated to Lord La Ware and Ladie Anne, his wife. 
Mr. Arnold Sorsby, to whose research I am indebted for my acquaintance with this book, informs me that at the British Museum there are three editions of a book on farming by Richard Surphlet, the last of which is edited by Gervase Markham and was published in 1616.

The book is dedicated to Lord Willoughby, and consists of servile sentiments, classical tags and some Hebrew phrases. Mr. Surphlet's preface, addressed to the "gentle reader," is largely a tirade against the female sex.

Mr. Sorsby tells me that the book itself is composed of extracts from classical authors and is a sort of compendium for farmers. Such human and animal medicine as occurs is largely drawn from the herbals.

Markham's only reference to Surphlet is in the dedication to Lord Willoughby's heir. The previous edition "belonged to your . . . . father, as the gift of a learned and well experienced gentleman, who in the translation took a long and well merited labour."

The will of a Richard Surflet which was proved June 26, 1606, will be given later.

Mr. Sorsby* has suggested to me that the anonymous author of Sloane MS. 3801 may have been Richard Banister himself. I am convinced that he is correct and that $I$ was in error in dating it $1630-40$; for in the "Craft of Surgery" by Flint South, edited by Sir D'Arcy Power, I find that on July 8, 1602, Richard Banester of Slyford, Surgeon, was examined and approved by the Court of the Barber Surgeons' Company. It will be recalled that the author of the MS. in question wrote from Sleaford. I think that the man who translated the book of Laurentius may be the Richard Surflet whose name occurs in Venn. It is possible that he may have been the son of the gentleman who was married in 1563, If the will (v. infra) be his he would appear to have been unmarried and to have left his money in trust to apprentice the most godly of the sons of three other members of the Surflet family to some honest and profitable trade. These may have been his brothers, though he does not say so. The will which follows is according to the common form of the time; it is chiefly remarkable for religiousness amounting to fanaticism. Richard Surflet was obviously a Calvinist of the most fanatical type, at the same time he was evidently a scholar, familiar with Greek, Latin and Hebrew. The inventory of his goods shews him to have been rather a dandy, and his library must have been rich in works on divinity and medicine. He was going to sea, possibly to Spain as he took Spanish money with him. At the same time he must have been anticipating cold weather, or he would hardly have noted the stockinges "very thick and hayrie, bought at Craconia (Cracow) by a Transilvanian embassadour."

* Vide Brit. Jl. of Ophthal., March, 1934. 
I hardly think that Surflet was going to sea as a naval surgeon. At this date James the First had just ascended the English throne; Spain had not recovered from the Armada; and I should surmise that Surflet was simply going abroad. One can imagine the difficulty the executor would have had in deciding which of the sons was the most godly; and if either of them were the ophthalmic quack I think he would have probably been ruled out at once.

I have given footnotes to elucidate the various odd terms which will be found in the inventory, as well as such books as I have been able to identify.

I am obliged to Mr. Harvey Bloom for the transcript of the will.

\section{The Will of Richard Surflet (P.C.C. Stafford, 434)}

As I came from the earth the common mother of all mankinde: soe I knowe I shall returne unto the same againe, and with others the workes of God be resolved into my first matter, and seeing the time as a thinge moste uncertaine, is unknown me, but nowe uppon this goinge to Sea more probablye approachinge, by reason of the longe and dangerous occurences dependinge thereon. I thoughte it my parte to set my thinges in order, that soo if God doo call me hence, I maye be the freer to wayne myselfe from worldly and transitorie thinges. And to have my mynde onely intente uppon these wherein true felicity is placed. And first I bequeath myselfe sowle and bodye to that most lovinge and mercifull God who hath given his sonne Jesus Christ, borne of a woman, to suffer death uppon the crosse for me and all the elect, nott doubting but that as he hath nombered my dayes and is of all sufficient power to restore me agayne in health and safetie to my Native Soyle (ife soe it seeme good to him in his infinite wisdome) soe he will after my dissolution (whether by land or sea) receave me for the same his Christes sake, into eternall blisse; forgivinge me all my synnes originall and actuall, imputinge unto me the full and perfect obedience of his deare and onely begotten sonne whereby I shall stande unspotted and blameless before his throane of justice, never to be called into judgement but to passe from death to life; as for the goodes which God of his mercie hath blessed me with all my desire is that they be all sould and turned into money, of the money I give to William Bingham, a carver dwelling in Gleane Alley in Southwark, thre pounde six shillinges eight pence. To Maister Travers and Maister Egerton twentie shillinges a peece. To Maister Bandeforde and Mr. Paget of Detford tenne shillinges a peece. To Mr. Crosley, whom I make Supervisor for the discharginge of this my wyll, and to receave whatsoever moneyes may any manner of way be due un to me, the somme of fiftie three shillinges and fower pence. To his wiefe tenne shillinges. And to every one of his daughters six shillinges eight pence. The Rest of all such moneys as shall remaine, I desire to be layed out in some lease as may be most proffitable either in the Cittie or Countrey: And the yearelye revenue growinge thereofe for the space of every six yeres to be bestowed in the placinge and stockinge of some one of the sonnes of Richard Surflete John Surflete or Robert Surflete suche as shall be ofe most hope for Godlines or towardlines, with some Religious and honest man, in some good and commendable trade; But the Revenue of the seaventh yeare I desire to be bestowed uppon the godly distressed and afflicted and this by mutuall intercourse to be conty nued from seaven yeres to seaven yeres to the full expiration of such of twentie one yeres, and ife it should please God to call Maister Crosley away by death before such tyme expired. Then my desire is that he would commende these partes and offices to be performed by some other honeste frende of his fearinge God, or else to gett Maister Travers or Maister Egerton or some other faithfull minister such as shall then be of good reporte like unto them here in the Citty to procure one to doe the same to which my last wyll and Testament made the first of March one thouzand six hundred and three I putt my hande and seale in the presence of us Hugh Evans, William Tilney, William Shambrooke, Abraham Webbe. By me Richard Surflete :-Left in the Cyttie.

An Inventorye of such goodes as I carie with me to the Sea or otherwise leave 
with my friendes in London made the day and yeare within wrytten. Imprimis one great vessell of bookes at Maister Theralde the Lynnen Draper his house in Fryday Streete at the Signe of the Maydens head and Unicorne, and in the same place one old hampear with nothing but trash. Item at Maister Crosley his house at the Goulden Lyon at the Stockes one hamper and in it a clock called an alarum, a great box with Surgery instrumentes a lesser box called a playste or box with surgery instrumentes, also some of silver and some of iron, a box with my letters of orders, a license to practise Physique my clocke plummettes and a canvas bag with sundry sortes of thinges in it. Item one rapyer and a dagger a grograine gowne ${ }^{1}$ with a velvet face cape and gurding, a velvet jerkin, a satten doublet. two stuff doublets, two paire of rounde cloth hose, one paire of hose of velvet panes and cannyons, ${ }^{1 i}$ one paire of new Jersie stockinges of fourtene shillinges pryce, one peece of dornix ${ }^{2}$ with curtaine ringes at it, one ball of velvet gurding, one newe clarke* faced with velvet, one rydinge clarke and an old paire of baces, ${ }^{3}$ one paire of bootes and spurres one cloth sadle with thre girthes a petterell ${ }^{4}$ and crupper, one bridle with bytt and bosses, six ruffe bandes of cambrick, one new hatt faced with velvet, one course sheete to wrap my apparrell in, one velvet muff, one velvet cape for a clarke upon cloth.

Taken with me to sea First one Truncke, one mayl thre boxes with lockes whereof one is made deskwyse, two gownes the one of stuffe the other of cloth. one clark faced with velvet, one hat one Dutch cap, one silcke quilted cap, one other cap of Sparta velvet, two fustian nightcappes seaven lynnen cappes, whereof one is a lyttle wrought with black silcke in a border about the edges and thre of the other are newe, five dozen and a halfe of falling bandes two dozen new hande towelles and as many tablenapkins handkerchers, two dozen and a halfe cuffes thre newe paire with black and white edging lace, and as many payres of old ones, two doubletes of stuffe, fower jerkins, one of silcke another of cloth, the two other of stuffe, one newe the other olde, two crane feathered fustian mandillions, ${ }^{5}$ two paire of drawinge breeches of the same, fower paire of clothe breeches, two trusses of canvas six paire of lynnen breeches six fustian wastcoates, eightene newe shirtes, and six old, thre paire of oiled leather lyninges five paire of lynnen stockinges whereof fower are newe, one paire of worsted stockinges blacke and newe, two paire of Jersey but old, a fowerth paire of woollen yarne newe, a fifte pair of russet cloth, and a sixte of whyte knytt ones very thick and hayrie, bought at Craconia ${ }^{6}$ by a Transilvanian Embassadour, newe shoes three paire, old shoes two paire one paire of pumppes and pantofles ${ }^{\tau}$ olde, a paire of slippers and olde paire of lyned moyles, but lyttle or nothing worne, one paire of newe Pennyston ${ }^{8}$ blancketes, three new paire of hose garters, two of crewell and one of silcke, one bedrugge newe, one woolbed and two pillowes, two fustian pillowberes ${ }^{9}$ newe, one mat, one brush for clothes, one headbrushe, a lookinge glasse, two combes of box in cases, a paire of snuffers, an extinguisher a wooden standish ${ }^{10}$ with penknife etc a fayre Inckhorne with a penner and sandbox two, and of the same, fower newe paire of gloves, an old motley clokebagge, bookes a hundred and eight or thereabouts and of name as followeth, one hebrew bible one Tremelius in fol. one English bible guylded and prynted at Geneva, a French bible, one Greeke Testament, one French Testament, Calvine on Deuteronomy and Job, Calvine uppon the Psalmes in Latin, one Institution and epistles, Beya his epistles, and confessions, Du Plessy against the Masse, Grinous workes Parkins ${ }^{12}$ workes fol. Daneus on the Lords Prayer his ethicks and Isagoge Christiana in 2 vol. One Polain Theses, and Theses Genouses one Perk in's ${ }^{13}$ problem, his booke, de predestinatione his prophetica and Specimen degestri, one Ursinus Catechisme Sculteti medulla patruum, Flores Doctorum, one small Tablebooke the drum of doomesday. Kewstubbes ${ }^{1 !}$ on the Commandementes. Deanuge's lectures, Virel's dialogues, Bakers ${ }^{15}$ lectures on the Creede, the harmony of confessions. Fenner's ${ }^{16}$ Theologia, the Councell of Trent. One Perkins of Sathan's sophistry. Hunter's Cosmographie, one sermon of repentance six small catechismes the goulden booke of the leaden Godes. Brocard on the Cantacles. Finch his divynitie, one treatise of fastinge set forth in Scotlande, one Immytacon of Christ. One forme of comon prayer, one monomachie of motives, Cartwright's ${ }^{17}$ little Catechisme wrytten, one other booke of the forme of common prayer etc, one other Catechisme with the text of the Quotations, Stephanus his concordance Fenners household discipline one destruction of smale vices, one other smale Cathechism. Fornelius ${ }^{18}$ his workes fol. Piso his methodus etc. Valverda ${ }^{19}$ 
his Anatomicall tables, Bannasters ${ }^{20}$ Anathomy, Weckers'21 special Antidotane, Parry ${ }^{22}$ his surgery, Schenkens ${ }^{23}$ his observations 2 vol. Penotus ${ }^{2+}$ de vera preparatione medicamentorum chymicorum, The Cure of diseases in remote Regions, Gratias $a b$ horto of East Indian Simples. Laurentius ${ }^{25}$ de Cresibus, Clowes ${ }^{26}$ his practise of Surgery, Botellus ${ }^{27}$ de missione sanguinis, Willichus ${ }^{25}$ de Urinarum probationibus Wecker's surgery in English, Rouseus ${ }^{29}$ de magnis hipp lienib, one great lexicon, one Thom : dictionary one dictionarium poeticum, Martinus Gramer, Paginus Epitome, Scotus Greeke gramer, Mathiolus of the facultyes of simpies. decimo sexto, one Taleus Rethorick, Cartwrightes Treatise of Fastinge, Phregius his pedagogus cne Licesthenes Apothegmes, Aristotles Sentences, Tullyes Sentences, Flores poetaeum, the small Greeke poets. Verons Phisickes, Daneus his Physicke, Ovids Metamorphosis, three small paper bookes. Bourne his Regiment for the Sea, one bounde paper booke conteyning onè quire folio, paper booke conteyning one Epitome of Mr. Cartwright uppon the Commandementes and twentie poundes in Spanish Ryalles

Commission to administer was granted to William Crosley, June 26. 1606.

A search of the Parish Register of King's Lynn by the Verger gave the burial of the daughter of a physician there in 1630, which seemed at first sight as if it might be a name like Surphlet; but the tracing which he sent makes it more likely to have been Curtis :"Margaret Curtes d. of Mr. Richard Curtys, a physitian."

I do not of course pretend that this paper settles the question as to who Mr. Surphlet, the quack oculist was. The testator may have been the translator of Laurrentius, but it is odd that he did not mention his own work in his inventory. We know that the quack died at Lynn; and it is to be assumed that the testator lived in London or Southwark. He probably died abroad, and proof of death must have been forthcoming for administration to be granted to his executor.

The will is of interest in many ways and partly as shewing what a medical man at that date thought fit to take to sea with him.

\section{FOOTNOTES}

1. A red silk gown.

2. Usually spelt Dornick, a species of linen table-cloth, used in Scotland, and originally made at Deornick, in Flanders.

3. Probably braces.

4. A horse's breastplate.

5. A soldier's coat.

6. Cracow, capital of Poland.

7. Slippers.

8. Possibly Penistone in Lancashire.

9. Pillow beer, a cover for pillow-case.

10. A writing desk for ink, sand, wafers, etc.

11. Panels and lappets.

12. William Parkins (1558-1602). A staunch Calvinist whose works were translated into Dutch, Spanish, Welsh and Irish. The most famous, his Armilla Aurea (1590) went to its 15 th edition in 20 years. Dict. Nat. Biog.

13. Vide supra Parkins.

14. Possibly John Stubbs or Stubbe, a puritan Zealot. (1543-1591). Dict. Nat. Biog. 
15. Possibly Sir Richard Baker (1568-1645), Religious and Historical writer. Dict. Nat. Biog.

16. Dudley Fenner (c. 1558-1587) Puritan Divine. His Sacra Theologia was published in 1585 . Dist. Nat. Biog.

17. Thomas Cartwright (1535-1603). A Puritan. Dict. Nat. Biog.

18. Jean Fernel (1506-1588). His Universa Medicina was published in folio in 1567.

19. Valverda de Hamusco. His Anatomical Tables (Rome, 1556) are well known.

20. John Banester (1533-1610).

21. J. J. Wecker, the author of De Sceretis, 1582. Antidotarium, generale et speciale. 1601.

22. Ambroise Paré.

23. Schenckius, James. Observations. Lib. VII. dc Veneris. 1597.

24. Penotus. 1602.

25. Laurentius, on Crises.

26. Clowes, the well known English surgeon. Surgeon to St. Bartholomew's Hospital.

27. Leonardus Botallus. Dr. Curatione per Sanguinis Missionem. 1583.

28. Willichius. Urinarum Probationes. 1582.

29. Rouseus was the author of some works but I have not been able to identify the one mentioned here.

\title{
REMOVAL OF THE WRONG EYE* \\ BY
}

\author{
H. M. TRAQUAIR \\ EDINBURGH
}

THE most terrible disaster which can occur to the ophthalmic surgeon and to his patient is "removal of the wrong eye."

It might be thought that this accident was merely a possible but unlikely danger about which teachers should warn students but which has never actually occurred. That was my impression when I wrote in $1916^{8}$ that by the use of local analgesia " the possibility, however remote, of such a calamity as its (the wrong eye's) removal is totally avoided." At that time I imagined that removal of the wrong eye was a hypothetical possibility rather than an actual fact, a view which had been to some extent previously expressed by Hermann Knapp ${ }^{2}$ when he wrote in 1898 " . . . . we should be on our guard lest we take the good eye out. This awful mistake is sensationally mentioned in text-books and periodicals; I do not know whether it has actually occurred, but the possibility is undeniable."

Knapp's statement was based on the literature before 1898. Of over sixty text-books on ophthalmology and ophthalmic surgery

* Received for publication, December 4, 1946. 